these negative factors and for the successful development of the industry, it is necessary to maintain the competitiveness of products on the global and domestic markets by improving the quality and reliability of the products.

\section{References}

1. Shmyhol N. M., Pavliuk T. S. Eksportnyi potentsial pidpryiemstv mashynobudivnoi haluzi zaporizkoho rehionu: suchasnyi stan, problemy, perspektyvy // Visnyk Zaporizkoho natsionalnoho universytetu. 2014. Vol. 3. P. 47-55.

2. Dovhun O. S. Dohovirni vidnosyny v konteksti rozvytku mashynobudivnykh pidpryiemstv: proceedings // Perspektyvy rozvytku ekonomika Ukrainy: teoriia, metodolohiia, praktyka. Lutsk: RVV «Vezha» VNU im. Lesi Ukrainky, 2009. P. 92-93.

3. Farynovych I. V. Tendentsii rozvytku mashynobudivnoi haluzi $\mathrm{v}$ ekonomichnomu rozvytku krainy // Naukovyi visnyk NLTU Ukrainy. 2009. Vol. 19.11. P. 83-88.

4. Bernstein L. A., Wild J. J. Financial Statement Analysis: Theory, Application and Interpretation. McGraw Hill, 2006. 738 p.

5. Brigham E. F., Ehrhardt M. C. Financial management: theory and practice. Thomson South-Western, 2008. 1074 p.

6. Fabozzi F. J. Financial Management and Analysis. John Wiley \& Sons, Inc., 2008. 1022 p.

7. Graham B. O., Meredith S. B. The Interpretation of Financial Statements. HarperBusiness Essentials, 2008. 135 p.

8. Finance Fundamentals of Corporate Finance. Vol. 1 / Whitehurst D. et al. 2003. 966 p.

9. Sabath R. E., Kubr M. Management Consulting, a Guide to the Profession // Journal of Marketing Research. 1977. Vol. 14 No. 3. P. 422. doi: $10.2307 / 3150794$

10. Yuksvyarav R. K., Khabakuk M. Ya., Leymann Ya. A. Upravlencheskoe konsul'tirovanie: teoriya i praktika. Moscow: Ekonomika. 1988. 240 p.

11. Ofitsiinyi sait Derzhavnoi sluzhby statystyky Ukrainy. URL http://ukrstat govua/

12. Bakuta A. V. Suchasnyi stan mashynobudivnoho kompleksu Ukrainy: problemy ta perspektyvy: proceedings // Problemy ekonomichnoho rozvytku v suchasnykh umovakh. Zaporizhzhia: Zaporizka derzhavna inzhenerna akademiia, 2012. P. 22-32. URL: http://www.zgia.zp.ua/gazeta/evzdia_2 022.pdf
13. Pro skhvalennia Kontseptsii Zahalnoderzhavnoi tsilovoi ekonomichnoi prohramy rozvytku promyslovosti na period do 2020 roku: rozporiadzhennia Kabinetu Ministriv Ukrainy 17 July 2013. No. 603-r // Baza danykh «Zakonodavstvo Ukrainy». URL: http://zakon0.rada.gov.ua/laws/show/603-2013-\%D1\%80

14. Ofitsinyi sait Holovne upravlinnia statystyky Ukrainy u Zaporizkii oblasti. URL: http://zp.ukrstat.gov.ua/

15. Korotkyi Yu. V. Mashynobudivna promyslovist Ukrainy: zdobutky ta perspektyvy // Naukovyi visnyk Mizhnarodnoho humanitarnoho universytetu. Seriia: «Ekonomika i menedzhment». 2015. Vol. 11. P. 117-120

\section{ОЦЕНКА СОСТОЯНИЯ МАШИНОСТРОИТЕЛЬНОЙ ОТРАСЛИ} УКРАИНЫ

Проанализированы показатели деятельности машиностроительных предприятий Украины в 2010-2016 годах. Определено, что машиностроение играет большую роль в укреплении экономического состояния государства, активно влияя на формирование показателей социально-экономического развития Украины. Сделан вывод о том, что все перечисленные проблемы в значительной степени вызваны отсутствием реальных источников финансирования, что вызывает ухудшение материально-технической обеспеченности, и соответственно, низкое качество и высокую себестоимость продукции.

Ключевые слова: машиностроительные предприятия, индекс промышленности, объемы производства, социально-экономическое развитие Украины.

Kyrylenko Liana, Postgraduate Student, Department of Accounting and Audit, Zaporizhzhia National University, Ukraine, e-mail: Sabrinalike1711@gmail.com, ORCID: http://orcid.org/0000-00030110-498X

Shmyhol' Nadiya, Doctor of Economic Sciences, Professor, Head of the Department of Accounting and Audit, Zaporizhzhia National University, Ukraine, e-mail: nadezdash@ua.fm, ORCID: http:// orcid.org/0000-0001-5932-6580

\title{
Serbov M. DEVELOPMENT OF VALUE ESTIMATION OF COSTS OF FRESHWATER RESOURCES OF THE WATER BASIN BY THE OBJECTS OF NATURE USE
}

Розглянуто методичні підходи до оцінки витрат на підготовку і використання прісноводних ресурсів водного басейну при різних видах господарської діяльності. Розглянута оптимальна стратегія безпечного і збалансованого розвитку економіко-екологічної системи водного басейну. Запропоновано схему вартісної оцінки витрат на невиробничі втрати природного ресурсу при його первинній та спеціальній підготовщі.

Ключові слова: прісноводні ресурси, оцінка втрат, витрати на підготовку природного ресурсу.

\section{Introduction}

Systemic and extremely negative anthropogenic processes occurring during the last decades, as well as errone- ous ideas about inexhaustibility and unlimited possibilities for self-purification of natural areas, resulted in significant disruptions in the development of economic and ecological systems. The world community unequivocally recognized 
the need to ensure the life of the world's population only if the consequences of economic activity are taken into account, in the future, to assess the capabilities of future generations in meeting their needs [1].

Taking into account the special importance of freshwater resources in social and economic development, the fact that the water and environmental crisis is primarily a component of the ecological crisis in Ukraine [2,3], it is relevant to study the valuation of freshwater resource costs by nature use objects.

\section{The object of research and its technological audit}

The object of research is the cost estimation of freshwater resources costs by the objects of nature use in the implementation of various types of economic activities. The use of a freshwater resource is proposed to be considered within the boundaries of Ukraine's water basins - the territorial socio-economic system formed by water objects of a diverse physical and geographical basis, which is a systemic formation in the context of the national economy of Ukraine [4-6]. It should be noted that the degree of administrative and territorial unity of the water basin, as well as the level of development of production forces and productive relations on its territory, allows for the integral development of the economic system of regions and the country. This approach is also a factor of stable, constant and dynamic growth based on the principle of interaction and autonomy of elements of a multifactor system. An important aspect of the stable functioning of this socioeconomic system is the existence on the territory of the water basin of economic complexes, as well as certain types of economic activity, the dynamics, the development of which should not raise the position of constancy for the integrity of the country's economic system.

Deep changes in the size and nature of industrial production over the past decades turned out to be not supported by the necessary improvements and changes in the technical and technological support of modern production, on which the state of the freshwater system directly depends. At the same time, it is necessary to emphasize that the volumes of fresh water consumption in Ukraine over the past 20 years have increased approximately two-fold. The main consumers of freshwater resources in the country are industry, followed by rural and communal households.

For today, Ukraine's freshwater resources are barely half of the country's optimal needs. In the average water year, the total fresh water reserves in Ukraine are close to $94 \mathrm{~km}^{3}$, of which not more than $56-57 \mathrm{~km}^{3}$ are available for use. In low-water years, the deficit of fresh water in the country is about 4 billion $\mathrm{m}^{3}$. It is felt in the basins of all major rivers of Ukraine, especially in the southeastern and southern parts of it [6].

According to the World Health Organization in terms of drinking water reserves of Ukraine takes the last place in Europe. This indicator, calculated in $\mathrm{m}^{3}$ /year for 1 person, in Ukraine is about $1700 \mathrm{~m}^{3}$, while in European countries it varies from $4570 \mathrm{~m}^{3}$ (France) to $24000 \mathrm{~m}^{3}$ (Sweden). At the same time, the average daily water consumption per inhabitant of Ukrainian cities (320 liters) is 2.5-3 times more average than in the large cities of Europe (100-200 liters).
The significant deficit of fresh water in Ukraine is aggravated by the extremely uneven distribution of its reserves throughout the country. This is due, first of all, to the nature of the relief, climate, water permeability of rocks, as well as features of soils, vegetation cover and the influence of other natural factors, factors underlying the surface. For comparison, most often use the density indicator of the river network, which is determined by the ratio of the total length of rivers to the total area of the territory (basin) over which they flow. In Ukraine, the largest density coefficient is typical for the river network of the Carpathians (up to $1.1 \mathrm{~km} / \mathrm{km}^{2}$ ), in the steppe regions of Eastern Ukraine between the Dnipro and Molochna rivers, this indicator is the smallest - up to $0.25 \mathrm{~km} / \mathrm{km}^{2}$. For example, for the equatorial zones of excess moisture, where the basins of some of the largest rivers in the world of the Amazon and the Congo are located, as well as the mountain river systems of the Tan Shan, this indicator can reach values of $2.5-3.0 \mathrm{~km} / \mathrm{km}^{2}$ [6].

A similar situation is observed in Ukraine and with the territorial distribution of groundwater resources. The main part of the forecasted groundwater resources (up to $51 \%$ ) is concentrated in the northern and northwestern parts of Ukraine, within the Dnipro and Volyn-Podolsky artesian basins, where the most favorable conditions exist for the formation of fresh groundwater. The greatest weight in the total amount of groundwater resources is occupied by the Chernihiv region - about 8.3 million $\mathrm{m}^{3}$ /day $(15 \%)$. Southern regions of Ukraine, given the extremely unfavorable climatic conditions of accumulation, have extremely limited groundwater resources. For example, in the territories of Dnipropetrovsk, Kirovohrad, Mykolaiv and Odesa regions, the maximum amount of reconnoitered groundwater resources per capita in the region is 15-20 times less than the corresponding figure for the Chernihiv region.

In general, the internal waters of the country have undergone significant anthropogenic and technogenic influence, which determines their modern water regime and properties. Therefore, the problem of water scarcity in the country is greatly strengthened by a very low quality of water resources. According to the World Health Organization, Ukraine occupies the 70th place in the world in drinking water quality. In general, the country has an extremely high ratio between water intake and discharge of wastewater (including untreated) waters [7, 8].

For example, according to data only in the Dnepropetrovsk region, about 1200 million $\mathrm{m}^{3}$ of untreated wastewater from various environmental management facilities are dumped into reservoirs annually. Extremely inefficient operation of wastewater purification plants leads to a daily discharge of up to 5 million $\mathrm{m}^{3}$ of contaminated wastewater. To date, most of Ukraine's water bodies contain water reserves of III and IY categories, that is, they are characterized as «contaminated water» and «dirty water» [6].

One of the most problematic places that are inherent in the object of research under the existing operating conditions is the lack of clear criteria and techniques that allow the valuation of freshwater resource costs at various stages of its preparation and economic use. In turn, these methodological approaches should form the basis for developing an optimal strategy for the safe and balanced development of the economic and ecological system of the water basin. 


\section{The aim and objectives of research}

The aim of research is the development of methodological approaches in the valuation of freshwater resource costs in the implementation of various types of economic activities by nature use objects.

To achieve this aim it is necessary to accomplish the following tasks:

1. To conduct an analysis of the costs of the preparation and use of freshwater resources for various types of economic activities.

2. To conduct an analysis of the costs of non-productive losses of natural resources with its primary and special preparation.

3. To develop a scheme for the cost evaluation of freshwater resource costs when preparing and using environmental management facilities.

\section{Research of existing solutions of the problem}

In recent years, the spectrum has expanded significantly, and various scientific researches have been significantly intensified in the issues of sustainable development of freshwater systems related to solving problems of optimizing the use of natural resources and improving the environment.

Today, the water management and hydroecological problems of Ukraine have acquired not only national, but also international significance. The water factor has become not only one of the main indicators that limit the development of the production sphere in the region, but also the unconditional paradigm of Ukraine's national security.

The methodological basis for the economic assessment of water resources costs in the implementation of various types of economic activities by nature management objects, including for the territory of Ukraine, was laid in the research of a number of scientists [1, 7, 9-12]. Particular attention in these studies has always been given to the analysis and assessment of freshwater resources as a basic natural factor that determines not only the level of development of the production sphere of the region, but also the social component of community life.

The water resource potential of any territory is the natural basis of its economic development and social and ecological well-being. At the same time, the current mastery and degree of economic pressure on the freshwater resource potential is greater than part of Ukraine has already reached such levels, which in most cases exceed its self-healing ability.

Among the main directions of the solution of the investigated problem, identified in the resources of the world scientific periodicals, can be singled out:

- in the development of the conceptual framework

for the economic evaluation of the natural resource potential in terms of sustainable development of the region [5, 11, 14];

- special attention is paid to the economic aspects of the theory of regional sustainable development in their works [15-18].

In particular, in the works [10, 13, 19] along with the economic and financial aspects of solving the considered problems, the issues of resolving institutional issues, as well as solving problems of environmental policy at different levels.
A somewhat alternative variant is proposed in [4, 21-23], which assumes that the main focus in solving this task should be on environmental protection in water basins, the development of modern low-waste and resource-saving technologies. The authors [7,9] have a special role to invest in the nature protection activities of Ukraine's water basins.

The authors of $[3,24,25]$ suggest a somewhat alternative approach to the solution of the problem, when the valuation of a natural resource is carried out in the context of the development of integrated water basin management schemes.

Despite the considerable amount of scientific research, the issues of methodological justification of the overall strategy of valuation of freshwater resources in terms of sustainable and safe development of economic and environmental safety of systems at the regional level - the level of the water basin - remain insufficiently studied.

\section{Methods of research}

To solve the tasks set in the work, methods of analysis and synthesis, comparative comparison, logical generalization and analogies were used in combination with monographic and graphoanalytical studies.

\section{Research results}

The essence of the current ecological crisis in Ukraine lies in the fact that human activity, formed due to the predominantly extensive development of the economy, requires an increasing number of freshwater resources of high quality [21, 24]. According to estimates of a number of foreign scientists, Ukraine's annual economic losses as a result of irrational nature management and environmental pollution make up about $15-20 \%$ of its national income.

To ensure an optimal strategy for the sustainable development of all components of the basin, a valid probabilistic assessment of both the occurrence of risks of a different nature and their quantitative impact on the factors of sustainable development of ecological and economic systems is of great importance.

The total costs of using freshwater resources should be considered as the total costs for the initial preparation of freshwater resources and the costs of direct use of the natural resource. This assessment should be carried out depending on the nature and quantity of water resources necessary to carry out this type of activity in the full required volume.

The above costs can be determined according to the following scheme:

- costs when carrying out household activities $C_{h}[6,7]$ :

$C_{h}=\left(C_{\text {prim }}+C_{\text {h.prep }}\right)$;

- costs associated with the implementation of economic activities $C_{e}$ :

$C_{e}=\left(C_{\text {prim }}+C_{\text {e.prep }}\right)$;

- when carrying out production activities $C_{p r}$ :

$C_{p r}=\left(C_{p r}+C_{p r . p r e p .}\right)$,

where $C_{\text {prim }}$ - the cost of primary resource preparation; $C_{h . p r e p}$, $C_{\text {e.prep }}, C_{\text {pr.prep }}$ - the cost of preparing a natural resource for 
direct use with, respectively, household, economic and production activities [6].

Then, the total costs $S_{t}$ for providing freshwater resources of all the above activities can be determined by a formula of the form:

$$
S_{t}=\left(S_{h}+S_{e}+S_{p r}\right)
$$

Total costs for the entire basin of a water body $S_{\text {t.bas. }}$, providing freshwater resources, all types of activities of economic entities within the water basin or a certain region (territorial unit) can be defined as:

$$
C_{t . b a s .}=C_{t .1}+C_{t .2}+\ldots+C_{t . n}
$$

where $C_{t .1}, C_{t .2}, \ldots C_{t . n \text {. }}$ - the costs of using freshwater resources out of $1 ; 2 ; \ldots \mathrm{n}$ sources.

Specific costs for the implementation of household $C_{\text {s.h. }}$, economic $C_{\text {s.e. }}$ and production $C_{t . p r}$ activities are determined by the following schemes:

$$
\begin{gathered}
C_{s . h .}=\frac{C_{h .}}{N_{h .}}, \\
C_{s . e}=\frac{C_{e .}}{N_{e}}, \\
C_{t . p r .}=\frac{C_{p r .}}{N_{p r}},
\end{gathered}
$$

where $N_{h}, N_{e}, N_{p r}$ - respectively, the total number of economic entities for various activities within the territory under consideration.

Specific costs for the preparation of freshwater resources for household $C_{\text {s.h/prep. }}$, economic $C_{\text {s.e/prep. }}$ and production $C_{\text {s.pr/prep. }}$ activities, and can be determined using a similar (6)-(8) approach:

$$
\begin{aligned}
& C_{\text {s.h/prep. }}=\frac{C_{h . \text { prep. }}}{N_{h .}}, \\
& C_{\text {s. e/prep. }}=\frac{C_{\text {e.prep. }}}{N_{e .}}, \\
& C_{\text {s.pr/prep. }}=\frac{C_{\text {pr.prep. }} .}{N_{p r .}} .
\end{aligned}
$$

Freshwater resources, passing through various technological processes, form polluted (circulating) wastewater that enter the wastewater purification plant (Fig. 1).

At the same time, it is necessary to take into account the quantitative indices of the natural resource necessary for the implementation of household $Q B_{h}$ economic $Q B_{e}$ and production $Q B_{p r}$ activities:

$$
\begin{aligned}
& Q B_{h}=\partial_{h .} \cdot N_{h .}, \\
& Q B_{e .}=\partial_{e \cdot} \cdot N_{e .}, \\
& Q B_{p r \cdot}=\partial_{p r} \cdot N_{p r},
\end{aligned}
$$

where $\partial_{h}, \partial_{e}, \partial_{p r}$ - indicators of the specific amount of water resources that provide, respectively, household, economic and production activities.

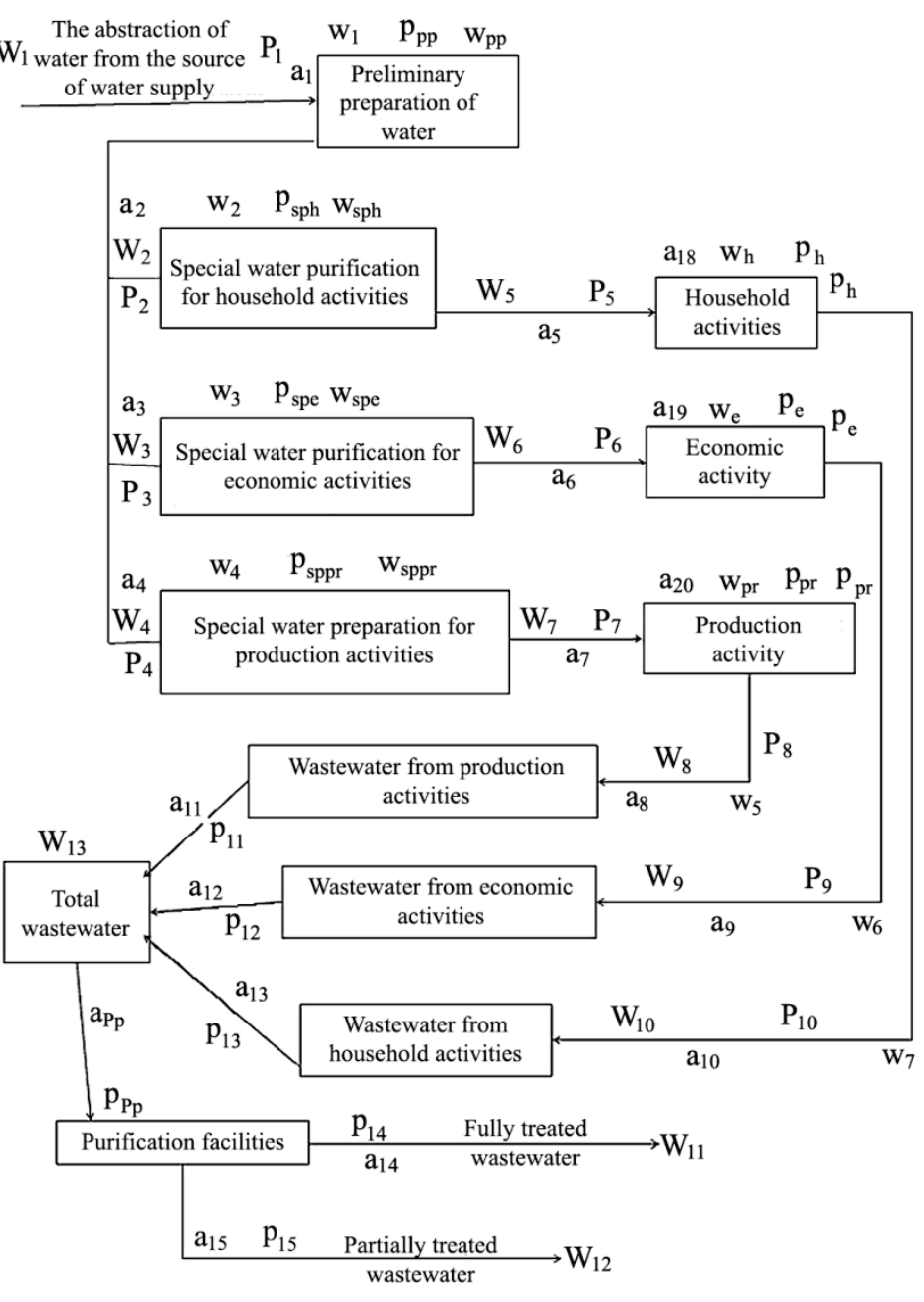

Fig. 1. The enlarged scheme of unproductive losses of freshwater resources in the implementation of production and economic activities [6]

In turn, the total amount of freshwater resources used to provide various types of activity of the objects of the economic complex of the territory $Q B_{t}$ can be calculated as:

$$
Q B_{t}=\partial_{f r} \cdot Q B_{f r},
$$

where $\partial_{f r}$ - the specific consumption of freshwater resources in the implementation of water purification; $Q B_{f r}-$ the amount of freshwater resources after water purification.

At the same time, the determination of total wastewater volumes that have undergone a complete purification cycle $Q_{p}$, or volumes of partially purified wastewater $Q_{p p}$ can be carried out using the following design scheme:

$$
\begin{aligned}
& Q_{p .}=\partial_{p .} \cdot Q_{\omega}, \\
& Q_{p p .}=\partial_{p p .} \cdot Q_{w .},
\end{aligned}
$$

where $\partial_{p}, \partial_{p p}$. - the specific amount of wastewater that has undergone, respectively, complete or partial purification, and $Q_{w}$ - the total volume of wastewater, which, taking into account the specific consumption of the freshwater resource for water purification, can be calculated as:

$$
Q_{w}=\partial_{f r} \cdot Q B_{t} .
$$


Taking into account the proposed scheme, the costs for carrying out household $S_{h}$, economic $S_{e}$ and production $S_{p r}$ activities can be defined as:

$$
\begin{aligned}
& S_{h .}=\partial S_{h .} \cdot P_{h .}, \\
& S_{e .}=\partial S_{e .} \cdot P_{e .}, \\
& S_{p r .}=\partial S_{p r .} \cdot P_{p r .},
\end{aligned}
$$

where $\partial S_{h}, \partial S_{e,}, \partial S_{p r}$. - unit costs, and, $P_{h}, P_{e .}$ and $P_{p r}$. volumes for, respectively, household, economic and production activities.

The conducted studies $[6,7,22]$ show that the financial costs of using freshwater resources for household, economic and production activities depend on the total volumes and unit costs for each type of activity. At the same time, the unit costs for providing freshwater resources to various types of activities are determined depending on the total amount of reverse wastewater and the specific indicators of their purification.

The above specific costs depend on the perfection of the used technologies, the equipment, the presence and magnitude of non-productive losses when transporting freshwater resources to the object of their use. Quantitative estimates presented in the works of a number of authors [7, 9, 10, 21] show that such unproductive losses often amount to about $40-50 \%$ of the total volume of the resource withdrawn from the natural environment.

The cost estimate of the costs of non-productive losses of freshwater resources during their transportation $S_{t r}$, the implementation of primary and special preparation $S_{\text {prep }}$ for subsequent use $S_{u s}$ can be carried out taking into account the unit cost estimates of non-productive losses [6, 8].

Similarly, the valuation of non-productive losses of the resource with its primary and special preparation, unproductive losses in the implementation of all types of economic activities is carried out taking into account the specific indicators of the corresponding costs and the total volume for each of the activities. Then the total valuation of the unproductive loss of freshwater resources is defined as:

$$
S_{t .}=S_{\text {tr. }}+S_{\text {prep. }}+S_{\text {us. }}
$$

Estimation of irretrievable and unproductive losses of water resources that occur during their transportation should be carried out taking into account the characteristics of the transport system used in the production of technologies, the culture of production and economic activities, the degree of personnel preparation. In this case, the transportation of the resource takes into account the routes:

- from water intake points to places of technological use; - supply of contaminated wastewater to purification facilities;

- conducting their preliminary and special preparation; - realization of technologies and methods of work by objects of an economic complex.

\section{SWOT analysis of research results}

Strengths. The strength of research is the universality of the proposed methodological approach, which is applicable to various spheres of economics and management of environmental management objects. The presented methodological approach is a sufficiently flexible tool with a free choice of elements of analysis, depending on the goals and objects of management.

Weaknesses. The weak side of research is the need to collect data, which today are represented by various nature use objects in extremely limited quantities, as well as data only in general indicators. The development of specific activities to achieve these goals requires additional research

Opportunities. Opportunities for further research are the borrowing of foreign experience in improving the analysis of existing methodological approaches to assessing the costs of water resources in the implementation of various types of economic activities.

Threats. Threats to the results of further research are the need to continuously improve the methods of economic analysis, taking into account a set of external factors of influence.

\section{Conclusions}

1. The carried out analysis of the costs of the preparation and use of freshwater resources for various types of economic activity shows the special significance of the probabilistic assessment of the occurrence of risks of a different nature. Their quantitative description as a factor of sustainable development of the economic and ecological system of the water basin.

2. The methodical approach and the enlarged scheme of definition of non-productive losses of water resources are offered at their primary and special preparation.

3. The methodical approach and the general scheme for determining the cost estimate of the freshwater resource costs in the course of its preparation and use by nature management facilities that take into account the overall volumes and unit costs for each type of economic activity are substantiated.

\section{References}

1. Pro skhvalennia Kontseptsii natsionalnoi ekolohichnoi polityky Ukrainy na period do 2020 roku: rozporiadzhennia Kabinety Ministriv Ukrainy 17 October 2007. No. 880-r // Baza danykh «Zakonodavstvo Ukrainy». URL: http://zakon0.rada.gov.ua/ laws/show/880-2007-\%D1\%80 (Last accessed: 15.04.2017).

2. Zastavnyi F. D. Ukraina. Pryroda, naselennia, ekonomika. Lviv: Apriori, 2011. 504 p

3. Yatsyk A. V. Ekolohichni osnovy ratsionalnoho vodokorystuvannia. Kyiv: Geneza, 1997. 640 p.

4. Prognozirovanie resursno-ekologicheskikh i ekonomicheskikh transformatsiy (na primere primorskikh regionov) / Burkinskiy B. V. et al.; ed. by Burkinskiy B. V., Stepanov V. N. Odessa: IPREEI NAN Ukrainy, 2004. 425 p.

5. Pryrodno-resursnyi potentsial staloho rozvytku Ukrainy Danylyshyn B. M. et al. Kyiv: RVPS Ukrainy, 1999. 716 p.

6. Serbov N. G. Vliyanie ekonomiko-ekologicheskoy situatsii na proizvodstvennuyu i khozyaystvennuyu deyatel'nost' v vodnykh basseynakh Ukrainy. Odessa: Izdatel' Bukaev V. V., 2015. 302 p.

7. Kovalev V. G., Serbov N. G., Rekish A. A. Proizvodstvennokhozyaystvennaya i prirodookhrannaya deyatel'nost' v vodnykh basseynakh Ukrainy / ed. by Kovalev V. G. Odessa: POLIGRAF, 2011. 105 p.

8. Serbov M. Methodological approaches in the valuation of freshwater resource costs when carrying out economic activities by nature use objects // Perspectives of research and development. Dublin: SAUL Publishing, 2017. P. 20-25.

9. Investirovanie prirodookhrannoy deyatel'nosti / Burkinskiy B. V. et al. Odessa: IPREEI NAN Ukrainy, 2002. 224 p.

10. Loyter M. N. Prirodnye resursy i effektivnost' kapital'nykh vlozheniy. Moscow: Nauka, 1974. 280 p. 
11. Mints A. A. Ekonomicheskaya otsenka estestvennykh resursov (nauchno-metodicheskie problemy ucheta geograficheskikh razlichiy i effektivnosti ispol'zovaniya). Moscow: Mysl', 1972. 303 p.

12. Palamarchuk M. M., Palamarchuk O. M. Ekonomichna i sotsialna heohrafiia Ukrainy $\mathrm{z}$ osnovamy teorii: textbook. Kyiv: Znannia, 1998. $416 \mathrm{p}$

13. Popovkin V. A. Povyshenie roli kompleksnykh territorial'nykh planov v ekonomicheskom i sotsial'nom razvitii. Kyiv: Znannya, 1986. $123 \mathrm{p}$

14. Dong C., Schoups G., van de Giesen N. Scenario development for water resource planning and management: A review // Technological Forecasting and Social Change. 2013. Vol. 80, No. 4. P. 749-761. doi:10.1016/j.techfore.2012.09.015

15. Dorohuntsov S. I., Mukhovykov A. M., Khvesyk M. A. Optymizatsiia pryrodokorystuvannia. Vol. 1. Pryrodni resursy: ekoloho-ekonomichna otsinka. Kyiv: Kondor, 2004. 291 p.

16. Dzhyhyrei V. S. Ekolohiia ta okhorona navkolyshnoho pryrodnoho seredovyshcha. Kyiv: Znannia, 2007. 422 p.

17. Granberg A. G. Osnovy regional'noy ekonomiki. Moscow: Izdatel'skiy dom GU VSHE, 2004. 495 p.

18. Chung G., Lansey K., Bayraksan G. Reliable water supply system design under uncertainty // Environmental Modelling \& Software. 2009. Vol. 24, No. 4. P. 449-462. doi:10.1016/ j.envsoft.2008.08.007

19. Priority water research questions as determined by UK practitioners and policy makers / Brown L. E. et al. // Science of The Total Environment. 2010. Vol. 409, No. 2. P. 256-266. doi:10.1016/j.scitotenv.2010.09.040

20. Bun E. K., Khens L. Ot deklaratsii tysyacheletiya - k Yokhannesburgskoy deklaratsii: uroki i perspektivy ustoychivogo razvitiya // Metody resheniya ekologicheskikh problem / ed. by Mel'nik L. G., Sabadash V. V. Sumy: Kozatskiy val, 2005. P. 211-224.

21. Rekish A. A. Ekonomicheskie, ekologicheskie, sotsial'nye osnovy razrabotki otsenok napravleniya razvitiya ekonomikoekologicheskikh sistem. Odessa: ODEKU, 2010. 125 p.

22. Serbov N. G. Ekonomicheskie osnovy ekologizatsii proizvodstvenno-khozyaystvennoy deyatel'nosti v vodnykh basseynakh
Ukrainy // Vestnik Dnepropetrovskogo universiteta. Seriya: Ekonomika. 2011. Vol. 19, No 10/1. P. 63-68.

23. Evaluating participation in WFD river basin management in England and Wales: Processes, communities, outputs and outcomes / Benson D. et al. // Land Use Policy. 2014. Vol. 38 P. 213-222. doi:10.1016/j.landusepol.2013.11.004

24. Naukovi zasady ratsionalnoho vykorystannia vodnykh resursiy Ukrainy za baseinovym pryntsypom / Stashuk V. A. et al.; ed. by Stashuk V. A. Kherson: Vydavnytstvo Hryn, 2014. 320 p.

25. Optimal sequencing of water supply options at the regional scale incorporating alternative water supply sources and multiple objectives / Beh E. H. Y. et al. // Environmental Modelling \& Software. 2014. Vol. 53. P. 137-153. doi:10.1016/ j.envsoft.2013.11.004

МЕТОДОЛОГИЧЕСКИЕ ПОДХОДЫ В РАЗРАБОТКЕ СТОИМОСТНОЙ ОЦЕНКИ ЗАТРАТ ПРЕСКОВОДНЫХ РЕСУРСОВ ВОДНОГО БАССЕЙНА ОБЪЕКТАМИ ПРИРОДОЛОЛЬЗОВАНИЯ

Рассмотрены методические подходы к оценке затрат на подготовку и использование пресноводных ресурсов водного бассейна при различных видах хозяйственной деятельности. Рассмотрена оптимальная стратегия безопасного и сбалансированного развития экономико-экологической системы водного бассейна. Предложена схема стоимостной оценки затрат на непроизводственные потери природного ресурса при его первичной и специальной подготовке.

Ключевые слова: пресноводные ресурсы, оценка потерь, затраты на подготовку природного ресурса.

Serbov Mykola, PhD, Associate Professor, Vice-Rector for Academic Affairs, Odessa State Environmental University, Ukraine e-mail:serbov@odeku.edu.ua,ORCID:http://orcid.org/0000-00020220-6745

\section{Kharenko D., Dyshkantiuk 0., Ivychuk L.}

\section{ANALYSIS OF GASTRONOMIC EVENTS: A CASE STUDY OF PORTUGAL}

Проведено дослідження традичійних гастрономічних фестивалів в Португалії. Визначено, наскільки іх конщепція задовольняє сучасні потреби відвідувачів в здобутті унікального досвіду. Результати дослідження підтверджують, що гастрономічні фестивалі мають великі соціальноекономічні перспективи для розвитку. Був проведений збір і обробка статистичних даних $і$ внаслідок аналізу дані рекомендащії щодо поліпшення маркетингової стратегї і дизайну подій.

Ключові слова: гастрономічні фестивалі, дизайн подї, організащія заходів, подієвий туризм, досвід відвідувачів, економіка вражень.

\section{Introduction}

The interrelation between gastronomy and tourism is currently undeniable, not only because it is an integral part of the tourist experience, but also because it is a trend [1]. In some cultures, cooking is seen as an art, and good cooks become celebrities. Each nation and nationality on Earth has unique culinary traditions. Obviously, it is possible to learn a lot about a country by its kitchen. Gastronomic tourism is gaining popularity among tourists looking for unique emotions, gaining a distinctive experience, taking part in local gastronomic events.
A modern trend in gastronomic tourism is that the consumer is more inclined to take an active position in getting sensory and emotional experience, rather than just being a passive consumer.

Gastronomic festivals, like events aimed at providing the visitor with bright sensory impressions - call for greater involvement of visitors in the process of producing gastronomic products. Thus, they receive a unique sensory experience, are attached to local cultures and interact with local residents. Active involvement of tourists in local traditions is a modern tourist trend. Thus, the quality of the tourist service provided is closely 